Winter 1993

\title{
The Discourse of Souls in Tana Toraja (Indonesia): Indigenous Notions and Christian Conceptions
}

Kathleen M. Adams

Loyola University Chicago, kadams@luc.edu

Follow this and additional works at: https://ecommons.luc.edu/anthropology_facpubs

Part of the Anthropology Commons, Religion Commons, and the South and Southeast Asian Languages and Societies Commons

\section{Recommended Citation}

Adams, K. (1993). "The Discourse of Souls in Tana Toraja (Indonesia): Indigenous Notions and Christian Conceptions." Ethnology, 32(1), p. 55-68.

This Article is brought to you for free and open access by the Faculty Publications and Other Works by Department at Loyola eCommons. It has been accepted for inclusion in Anthropology: Faculty Publications and Other Works by an authorized administrator of Loyola eCommons. For more information, please contact ecommons@luc.edu. (c) (1) $(9)$

This work is licensed under a Creative Commons Attribution-Noncommercial-No Derivative Works 3.0 License. (c) University of Pittsburgh, Department of Anthropology. 1993. 


\section{University of Pittsburgh- Of the Commonwealth System of Higher Education}

The Discourse of Souls in Tana Toraja (Indonesia): Indigenous Notions and Christian Conceptions

Author(s): Kathleen M. Adams

Reviewed work(s):

Source: Ethnology, Vol. 32, No. 1 (Winter, 1993), pp. 55-68

Published by: University of Pittsburgh- Of the Commonwealth System of Higher Education

Stable URL: http://www.jstor.org/stable/3773545

Accessed: 01/09/2012 12:31

Your use of the JSTOR archive indicates your acceptance of the Terms \& Conditions of Use, available at http://www.jstor.org/page/info/about/policies/terms.jsp

JSTOR is a not-for-profit service that helps scholars, researchers, and students discover, use, and build upon a wide range of content in a trusted digital archive. We use information technology and tools to increase productivity and facilitate new forms of scholarship. For more information about JSTOR, please contact support@jstor.org. 


\title{
THE DISCOURSE OF SOULS IN TANA TORAJA (INDONESIA): INDIGENOUS NOTIONS AND CHRISTIAN CONCEPTIONS
}

\author{
Kathleen M. Adams
}

Beloit College

In Insular Southeast Asia, indigenous religions are oriented more towards practice than philosophy. Geertz's (1973:177) observations concerning religion in Bali generally hold true for other autochthonous religions of the Indonesian archipelago: "Beyond a minimal level there is almost no interest in doctrine...The stress is on orthopraxy, not orthodoxy." Accordingly, discussions of indigenous notions of the soul in insular Southeast Asia rarely center on philosophical doctrine. Rather, local practitioners tend to emphasize ritual obligations to souls at various points in time, enumerating the requisite rites to aid souls in their afterlife journeys (cf. Fox 1973; Weinstock 1987). This essay is broadly concerned with the relationship between such amorphous practice-centered indigenous conceptions of soul and subsequentlyintroduced Christian metaphysical propositions.

Recently, Indonesianists studying processes of religious transformation have prompted us to recognize the dynamic interplay between world religions, national politics, and indigenous religions (cf. Atkinson 1983; Kipp and Rodgers 1987). Atkinson (1983), for instance, has elegantly demonstrated how the construction of the Central Sulawesi Wana religion is rooted in a dialogue with both world religions and nationalist Indonesian civil religion. In a similar vein, Hoskins (1987) illustrates how the redefinition of Sumbanese spirit worship as a "religion" resulted from exposure to the doctrine of the Christian church and the Indonesian government. On Sumba, what was once a system of ritual practices and regulations became transformed into a system of beliefs.

Taking such notions of religions in dialogue as a starting point, this essay examines indigenous and Christian conceptions of the soul among the Sa'dan Toraja of upland Sulawesi. While Hoskins and Atkinson give more attention to the influence of world religions and national politics on local belief systems, my major focus in this paper is on the other side of the dialogue. That is, I am particularly concerned with the ways in which Christian Torajans incorporate and reformulate indigenous conceptions of the soul. Ranger (1987:183) has stressed the ironic aspect of African Christianity, noting that the dialectic between local religions and Christianity evolves in ways that confound both missionary and indigenous expectations. In this essay I examine how, for Christian Torajans, indigenous and Christian notions of soul not only coexist, but intermingle and at times compete. 
This essay begins with a discussion of the indigenous Torajan conception of the soul. One should note, however, that several factors have encouraged a more formal elaboration of their notions of soul. These factors include Torajan exposure to doctrine-centered world religions, the Indonesian government's 1969 recognition of Torajan Aluk to dolo as an official religion, and the queries of anthropologists and tourists visiting the Toraja highlands. After examining indigenous notions of the soul, I contrast these with the Dutch Reformed Church's vision of the soul. The final section addresses lay Christian Torajans' approach to the concept, and suggests that there is a discernable pattern to those indigenous ideas about the soul that persist.

\section{ETHNOGRAPHIC BACKGROUND}

The Sa'dan Toraja people are primarily wet-rice farmers inhabiting mountainous Tana Toraja Regency in the province of South Sulawesi, Indonesia. Most Torajans speak both Tae' Toraja, an Austronesian language closely related to other South Sulawesi languages (Mills 1975), and the national lingua franca of Bahasa Indonesia. In a multi-ethnic nation of 185 million people, the Toraja are a minority group numbering approximately 350,000 .

Torajan society is hierarchically organized on the basis of age, descent, occupation, and wealth. Traditionally there were three basic ranks: the aristocracy (to parengnge ); commoners (to buda, to sama); and serfs or slaves (kaunan). ${ }^{1}$ Today slavery is illegal and the topic of rank can be sensitive.

Before the Dutch colonial incursion into the Sulawesi highlands, Torajans resided in scattered mountaintop households, maintaining social ties through an elaborate system of ritual exchanges (Nooy-Palm 1979, 1986; Koubi 1982). For these Torajans the religious, political, and agricultural worlds were integrated and bound together by a system of ritual practices known as Aluk to Dolo (Ways of the People Before). ${ }^{2}$ It was not until Dutch forces conquered the highlands in 1906 that Torajans were united under a single political authority. With the upheaval caused by the expanding activities of Dutch colonialists and missionaries came the gradual coalescence of Torajan ethnic identity (Bigalke 1981). Today, over 80 per cent of Torajans have converted to Christianity: only 11 per cent of the population remain faithful to Aluk to Dolo (Kantor Statistik 1983).

\section{INDIGENOUS CONCEPTIONS OF THE SOUL}

For adherents of aluk to dolo, the nature of the soul is rarely a topic of metaphysical discourse (Crystal and Yamashita 1987). My inquiries about indigenous notions of the soul often left my aluk to dolo friends perplexed. They cautioned me that neither the English word soul nor the Indonesian term arwah could be easily translated into the Sa'dan Toraja language. What emerged from our conversations was a cluster of concepts associated with different states of the life force. The Toraja terms most often volunteered in such discussions were sumanga', penaa, bombo, and deata. I examine each of these concepts below. 


\section{Sumanga': Animating Force}

The term sumanga' roughly translates as soul, spirit or consciousness and is closely related to the Indonesian word semangat (Tammu and van der Veen 1972:578). Sumanga' is present in all living things, although a sudden fright may prompt it to flee or a malevolent entity may appropriate the sumanga' of others. When describing an unexpected shock, I often heard Torajans proclaim, "My sumanga' flew off," or "His sumanga' left" (masso sumanga'na', pa'de sumanga'). As Coville (1988:155) observes, sumanga' has a bird-like quality, prone to flying off. The term sumanga' also appears in the ubiquitous phrase kurre sumanga', which is the standard way of expressing thanks. Literally, kurre sumanga' translates as to call the animating force (as one calls chickens). This phrase is common in the old aluk to dolo litanies such as the Passomba Tedong, where it is used to hail the ancestors (van der Veen 1966).

According to Bigalke (1981:200), Torajan head-taking was probably once linked to the notion of enhancing the power of sumanga', which was thought to reside in the head. Bigalke (1981:201) further hypothesizes that the importance of sumanga' declined after the seventeenth century, when shifting political alliances led to a dramatic limitation of the number of groups from which it was acceptable to take heads. In contrast, Downs (1955) and Needham (1976) have questioned classic Indonesian literature which interprets head-hunting as a quest for "soul substance." Whatever the case, it is clear that for Torajans today, sumanga' is more a vague notion of animating force than it is a powerful concept on which action is based. ${ }^{3}$

\section{Penaa: Soul of the Living}

By far the more common gloss for soul or life-force in the Kesu' area of Toraja is the term penaa. Penaa closely resembles sumanga', although it carries with it a sense of connection to the social world that Torajans do not allude to in describing sumanga'. Like the original Judeo-Christian concept of soul (MacGregor 1987:455), penaa connotes breath, but can also mean heart or spirit. For Torajans, penaa is the vital breath, the heart, the essence of the living person. One's penaa responds to everyday social and physical experiences; it grows larger after a hearty meal and smaller after physical exertion, illness, or distress. One Torajan who had consumed a bit too much palm wine, sadly recounted his anguish over not being able to marry the woman he loved, and sighed several times that his "heart/breath was small" (penaa bitti ). ${ }^{4}$

Unlike sumanga', which is prone to flying off and disappearing altogether, the vital breath interacts with the world. It responds to the actions of others. For instance, it can be coaxed into growing. When one young Torajan I knew was ill, her parents diligently forced her to eat heaping bowls of rice mush so that her heart/breath would get big. Similarly, when I did not receive letters from home for several weeks, the postal clerks joked that they would write me so that my penaa would not get small.

It is noteworthy that penaa not only refers to the essence of the living individual, but implies a link to others. I was often told that a family or group should be "of one breath/heart" (misa penaa). In other words, consensus is prized and individualism 
disdained. Coville (1988:163) has astutely observed that the Torajan concept of vital breath (penaa) articulates the interdependence of self and society. Thus, while the vital breath is the essence of the individual, the individual is inextricably bound to the group. This aspect of the Torajan concept of the soul contrasts with the Western Judeo-Christian notion which tends to perceive the individual soul as an autonomous entity.

In summary, penaa refers to the soul of someone in life and reflects a connectedness to others. When one dies, the vital breath departs (Pa'de mo penaana). The penaa apparently vanishes and, instead, Torajans speak of the bombo.

\section{Bombo: The Soul of the Soon-to-Die or the Dead}

When a Torajan is not long for this world, his or her soul may begin to wander. This wandering soul of the soon-to-die and the soul of the dead are both called bombo. ${ }^{5}$ The bombo is more personalized than the penaa: it resembles the deceased in appearance. Although often clothed entirely in black, bombos are also known to appear wearing the individual's favorite sarong, hat, and wristwatch.

Certain Torajans have the ability to see the wandering bombo of the soon-to-die. These para-normal individuals are called to patiro bombo. It is improper to say whose bombo they saw; until the individual dies, it may only be described. One was described to me as a "hunched-over grand-mother with long grey hair." Another was a "strong man in his 50 s or 60 s wearing shining new black shoes that squeaked." Some to patiro bombo claim they were born with this capability, others say that if one peered over a to patiro bombo's shoulder at a bombo, the ability to see bombo would be transferred.

Bombos are frequently sighted at funeral rituals. Torajan adherents of aluk to dolo do not declare an individual dead until after the completion of the funeral rites. During the funeral ritual, the soul (bombo) is believed to hover in the area. For those nobles whose families can afford an elaborate seven-day funeral entailing the sacrifice of at least 24 water buffaloes, finely-adorned effigies of bamboo or jackfruit wood may be fashioned. This tau-tau or bombo dikita (literally, soul that is seen), houses the soul of the deceased. On the first or second day of the funeral ritual it is paraded to a special stand, along with the body of the deceased. From this stand, the effigy (and bombo) watches over the mortuary activities in the ritual field below. Over the course of the next few days, the effigy observes the long processions of gift-laden guests, water buffalo fights, cock fights, animal sacrifices, and meat division. In the evenings the effigy hears the ponderous ma'badong chant; an all-night circular dance involving a recital of the life-history of the deceased. At the funeral's conclusion, the effigy is inserted in a cliff-side balcony or cave, along with the other ancestral effigies. ${ }^{6}$

The fortune of the soul depends upon the descendents' successful orchestration of the funeral rites. A botched funeral can cause a soul to hover indefinitely in this world, until the living make reparations. If all goes well, after the culmination of mourning rituals, the soul travels to Puya (the Land of the Souls), bringing with it all of the wealth and livestock sacrificed at the funeral. Puya is thought to be located 
somewhere in the distant southwest. While in my area, people believe that souls proceed directly to Puya where they are greeted by Pong Lalondong, in other regions, people describe the journey to Puya as arduous and filled with obstacles. ${ }^{7}$ Although Pong Lalondong, the master of Puya, is often said to act as judge, people could not elaborate on this. It is possible that his status as judge has evolved or expanded as a result of exposure to Christian conceptions of divine judgement. At any rate, Pong Lalondong's role was down-played by my aluk to dolo informants. For them, it appeared that entrance at Puya was directly related to the adequacy of the funeral ritual staged by one's relatives.

\section{Souls and Spirits that Remain in this World}

Some souls never make it to Puya. Those bombo whose funerals were never completed remain in this world pestering the living. Similarly, the bombos of lepers and those who committed suicide may not enter Puya, but are condemned to wander the earth. Particularly dangerous are the bombos of those who have died unjustly, as they roam about seeking vengeance. Such bombos inspire fear at night, even on the part of Christian Torajans. When Torajans return from funeral rituals after dark on lonely mountain paths, the mood is often apprehensive. The leader of the group may then solemnly swish a banana leaf or bamboo stalk in front of him as he walks to alert the bombo so that they would not be startled and react with anger.

Some of the spirits that remain on this earth troubling the living have special names. Silakku', for instance, are the souls of stillborn children or infants who died before cutting teeth. Their bodies are placed in a tree and their souls are said to subsequently move into particular birds known for their haunting night call. These calls inspire fear, as some Torajans believe that silakku' bear news of death.

Certain classes of spirits may possess the living, using them to execute their evil deeds. For example, batitong are humans inhabited by the angry souls of pregnant women who died in childbirth. ${ }^{8}$ By day they live as ordinary men or women, but by night they become exceedingly dangerous. They have a voracious appetite and greedily consume human livers, livestock, and feces. They move very swiftly and are said to look human, with glowing lights on their heads. Batitong inspire panic among both aluk to dolo and Christian Torajans. When living with a Christian family I was awakened late one night to crashing noises and terrified shouts of "Batitong! Batitong!" As I huddled with the other females in the center of the house, the older men crept out the back door, armed with sticks. They returned and announced that they had seen someone fleeing and discovered that the household chickens were missing. The women concluded that it was undoubtedly the work of a batitong. No one went back to sleep that night.

Although the batitong's status as part human/part spirit is somewhat an anomaly, it appears that most of the aberrant souls that remain on earth troubling the living share one quality; they tend to be the souls of individuals who were not full participants in the community. Small infants who perish have not yet become a part of the social group. Lepers, too, are marginal. Likewise, those who kill themselves act in isolation of the community's orientations, threatening the harmony of the group. 
Again we see a link between community and soul: the fate of one's soul seems to be determined, in part, by one's relationship with the community. But the destiny of most souls is Puya.

\section{Worlds in Discourse: Link Between Living and Deceased Souls}

Puya closely resembles the world of the living (Tangdilintin 1981). The hierarchical relations of this world continue in Puya, where one finds nobles, commoners, and slaves. People reside in houses similar to those they had while alive. Rice fields are planted, livestock is bred, and ritual celebrations are held.

After the soul arrives in Puya, the relationship between the living and the bombo does not abruptly end. Bombo may return to the living in dreams, particularly when they feel forgotten or when their descendants are in need of help. In addition, the living can communicate with the souls in Puya with the assistance of a specialist (To Pullondongan). Torajans delight in telling stories of such encounters. One frequently recounted tale involves a villager whose husband had died quite unexpectedly.

Before her husband's death a neighbor had given him some gold to be crafted into a necklace and now the neighbor wanted it back. The bereaved widow hunted everywhere for the gold, to no avail. Finally, she went to see the To Pullondongan, who said he could bring her to her husband in Puya, as long as she was calm and did not cry. They walked down the village trail together and she suddenly found herself at the entrance to Puya, where the gatekeeper Pong Lalondong asked her what she wanted. After explaining that she was from earth and had to ask her husband something important, she was allowed in. She found her husband in a house that looked just like theirs on earth. After telling him how much she missed him, she asked where he had put the gold. Her husband told her it was wrapped in a red cloth on one of the bamboo rafters of the house and cautioned her not to disturb it until the neighbor came for the gold. She returned to earth, checked the bamboo rafter and saw the red cloth but did not touch it. A few days later when the neighbor again came to ask for his gold, she told him of her trip to Puya. Together they took down the red cloth and found the gold wrapped inside.

Such stories are revealing in that they convey a critical aspect of the Torajan notion of soul--that there is a continued relationship between the living and the dead. Death and the completion of the funeral rites do not end relationships.

\section{Deata}

Once a bombo is in Puya, if the living stage an elaborate conversion ritual, certain bombo may leave Puya and ascend to the heavens where they are transformed into deified ancestors (deata). ${ }^{9}$ This movement of the soul from the realm associated with death (in the southwest) into the realm of the gods and the life force (in the northeast) is referred to as "bombo mendeata." Deata are small and golden in color, reside in the heavens, receive ritual offerings from their descendants, and provide protection and prosperity in return.

Two observations on the nature of the indigenous concept of soul emerge from this discussion. First, the Toraja approximation of soul involves several distinct concepts, 
each associated with a different state of the life force. A combination of sumanga'/penaa animate the living, bombo is the soul that emerges when one dies, and when the dead soul ascends to the heavens and transforms into a life force, it becomes a deified soul (deata).$^{10}$

Second, the individual's soul is intimately linked with the community. Most notably for aluk to dolo practitioners, neither the gods nor the individual fully determine the ultimate destiny of one's soul. Rather, through the successful orchestration of the funeral rites and, if one is privileged, subsequent rituals, the living community controls the soul's movement from this world to Puya and perhaps on to join the deities in heaven. After death, as in life, the Torajan individual's soul is oriented by the group.

\section{EVANGELICAL CONCEPTIONS OF THE SOUL}

In 1913, the first missionaries of the Dutch Reformed Church arrived in Tana Toraja, bringing with them a new epistemology that presented a fundamentally different notion of soul. For these devout Calvinists, the soul was not a descendantguided spirit but a foreordained and discrete entity. A cornerstone of their faith was the belief that God predestines certain souls to salvation and others to damnation. Moreover, humans could not alter the fate of their souls through ritual manipulations, pilgrimages, or penances. Simple faith and a reliance on the scriptures as an infallible guide were the signs of grace.

These Calvinist missionaries had been schooled in the proselytizing techniques of the celebrated Dutch missionaries Adriani and Kruyt, who had established an active mission in Central Sulawesi in 1892. Adriani and Kruyt advocated obtaining a thorough understanding of the indigenous culture in order to manipulate the local systems into accommodating Christianity. As Bigalke (1981:145) summarizes, "[These missionaries felt that] tinkering with symbolic systems rather than overhauling them posed fewer problems with internal reaction and promised a more genuinely held Christianity." By the second decade of proselytizing in the highlands, the missionaries had begun the task of sorting out which elements of Torajan beliefs and practices constituted traditions (adat) that could be left intact and which were religion (agama) and hence threatening to the church's goals. For the Dutch missionaries, several facets of Torajan soul beliefs were in direct conflict with Calvinist doctrine and became targets for suppression.

Torajan devotion to ancestral spirits and deities became an immediate area of concern for the evangelists. Van de Loosdrecht, the first missionary to Tana Toraja and a devotee of Adriani and Kruyt's methods, attempted to tackle the problem by selecting one of the Torajan deities (Puang Matua) ${ }^{11}$ to be transformed into the supreme Christian God. Other deities in the Torajan pantheon were then depicted as his servants (Bigalke 1981:219). According to Bigalke (1981:218-219),

The mission's systematic isolation of Puang Matua accelerated the process of rationalization already at work in the traditional religion. Soon Puang Matua stood virtually alone in the pantheon of high deities that reigned over a lower tier of deata...Coinciding with the accelerating process of social stratification and political centralization of the Torajan 
microcosm, this rationalized view of the macrocosm found supporters even among headmen who chose not to convert to Christianity.

Although the missionaries successfully reduced the importance of all but one of the Torajan deities and ancestral spirits for Christian (and some aluk to dolo) Torajans, their tinkering did not put an end to Torajan ritual feedings of the spirits. By 1923, the council of missionaries took more drastic measures, publicly forbidding all Christian Torajans to worship or make offerings to ancestral spirits and gods. Moreover, Christian Torajans were admonished from partaking in all smoke-rising or life-oriented rituals, as multiple deities and ancestral spirits were integral to these rituals (Bigalke 1981).

The evangelists found the Torajan notion of bombo especially discordant with Calvinism. According to Protestant conceptions, when one dies one dies completely. The soul does not linger on earth and there is no discourse between the living and the dead. Thus, at a 1928 conference, missionaries determined to forbid Christian Torajans to use tau-taus, which were traditionally thought to house the soul of the deceased (Sarira 1975:36). ${ }^{12}$

For similar reasons, funeral rituals were also problematic for the Dutch evangelists. The Torajan notion that the souls of animals sacrificed at funerals would accompany the deceased to Puya where they would live much as they did on earth evoked particular concern among the missionaries, as their scripture-based vision of the cosmos entailed a discontinuity between this world and the next. While the missionaries recognized that it would be difficult to alter funeral sacrifices, ${ }^{13}$ they stressed that these animals' souls and the valuables inserted in graves do not accompany the soul of the deceased to heaven. In the Protestant conception, after death the soul would have no need for these material things.

Moreover, the missionaries preached that the soul is called by God; wealth and the actions of one's kin could not affect one's destiny. This contrasted with the aluk to dolo notion which made the group of living descendants (rather than God) responsible for the soul's movements. Specifically, the bombo of the deceased could only move from this world to Puya (and, if from a wealthy elite family, on to the heavens to become a deified ancestor) if the living descendants performed the proper rituals. Although the missionaries did not dismantle all mortuary rites, they emphasized that the ritual activities of the living cannot "buy" a soul's salvation: the doctrine of predestination meant that God alone determines the soul's ultimate destination.

Thus, the Dutch Reformed Church missionaries' concept of the soul contrasted markedly from indigenous notions. The main points of contrast can be summarized as follows:

(1) In the aluk to dolo conception, the ultimate destiny of the soul is based on the actions of the living group of descendants whereas in the Christian conception, it is not the survivors but God who determines where one's soul retires.

(2) The aluk to dolo vision of soul requires continuity between this world and the next, whereas the Christian vision is of two discrete realms. For aluk to dolo adherents, the bombo lives in Puya as it lived on earth, with the same material needs it had when alive. Moreover, relationships with the living are not severed; through 
dreams and specialists, communication persists beyond the grave and the deceased could grant favors or terrorize the living. In the missionaries' vision, death brought a complete separation of body and soul and a complete severance of ties with the living.

(3) A social hierarchy is inherent in the aluk to dolo conception of soul, whereas the Christian conception of soul has egalitarian implications. According to aluk to dolo, only the souls of wealthy nobles could go on to become deified ancestors ${ }^{14}$, whereas for Christians one's rank does not determine whether one's soul is destined for salvation or eternal damnation.

\section{PARALLEL WORLDS IN DIALOGUE}

The head of the household in which I resided during my field research had been a past Secretary of the Protestant Toraja Church and was celebrated as a local culture expert. Early in my stay I asked him about Torajan spirit beliefs. "Spirits and ghosts?" he slowly repeated. Gesturing first to the stream that fed his rice field and then to the mountains fringing the horizon, he answered, "They used to be all over, in the stream, by the graves...but then Christianity came and drove all the spirits away into the hills of Mamasa." Months later, my devout Christian hosts warned me not to take a planned trip to that region "where the bombo roam and where there are still many aluk to dolo people who can make the dead walk." Comments like these soon had me wondering whether Christianity had eradicated Torajan spirit beliefs. Instead, it seemed, Christianity had relocated the realm of the spirits. It still existed, quite literally, at the fringes of the Christian Torajans' habitat. ${ }^{15}$

Several months later, I travelled with a prominent Protestant politician to his natal village. He elaborated on this image of the aluk to dolo world as a realm parallel to that of the Christian realm, as he expressed his concerns about his elderly aluk to dolo mother's resistance to converting to Christianity. If she died before converting, he explained, he would be obliged to sponsor aluk to dolo funeral rites for her, a most uncomfortable prospect for a prominent Christian Torajan such as himself. Thus, he used each visit with his mother as an occasion to gently persuade her to convert to Christianity.

When he discussed the subject with his mother, he focused on how, if she remained aluk to dolo, she would end up in Puya while all of her Christian children and grandchildren would be in heaven; thus, the much-prized family unity would be shattered. (She eventually retorted that he and his children could also insure family togetherness beyond the grave by returning to aluk to dolo.) Talking with him again on the return home convinced me that his portrait of separate, parallel after-worlds was more than a clever manipulation of Torajan devotion to family unity in order to convert his mother. This conception of parallel worlds was genuinely vivid for him.

For many Christian Torajans, the aluk to dolo world has been devalued, but not destroyed. Puya has not been dispensed with as an erroneous Animist belief; rather, it continues to exist, albeit uninhabited by the souls of Christian Torajans.

An event illustrating Christian Torajans' conception of parallel Christian and aluk to dolo worlds involves the effigies of the dead (tau-tau), traditionally believed to 
house the souls of the deceased. Over the past decade, these carved images have become increasingly coveted by ethnic art collectors and dealers in the western world, prompting a rash of tau-tau thefts. During an all-night funeral ritual attended by everyone in my village, thirteen of the ancestral effigies were stolen from the cliffside graves behind the village. The theft devastated the villagers. Christian Torajans sobbed that their ancestors had been abducted and ruminated over what course of action to take. Ultimately, they decided to lock up the remaining effigies and call in an aluk to dolo priest (to minaa) to conduct what these Christian Torajans termed "rites of apology to those whose effigies were stolen." Calling in a traditional priest to officiate in the realm of their aluk to dolo ancestors was a natural course of action for them. They showed no sense of unease or conflict about this decision. Although not directly articulated, in their minds, the Christian world did not replace the aluk to dolo world of ancestral spirits, but it existed parallel to it.

When I first concluded that although these two parallel worlds existed for Christian Torajans, I assumed there was no dialogue between them. But after I had lived in the village for several months, I had a nightmare involving a female ghost, and my cries prompted others to awaken me. When I recounted the dream, they looked at each other wide-eyed and said, "We didn't think you could see her..." I then learned that a female ghost periodically roamed the house. She was the bombo of a midwife who had once lived there, and no one in the family was willing to sleep in what had once been her room. When word got out in the village that I had "seen" a bombo, many Christians began shyly whispering to me about the various local spirits and bombos. It was then apparent that Christianity had not "driven out all the spirits" after all. Bombos were still around and troubled not only aluk to dolo Torajans but Christians, as well.

Moreover, the souls of the deceased (both Christian and aluk to dolo) continue to communicate with lay Christian Torajans through dreams. After Ne' Ke'te' (a pseudonym) died, his youngest son became quite ill. Several people in the village dreamt that $\mathrm{Ne}^{\prime} \mathrm{Ke}$ 'te' missed his much-adored ten-year-old boy and planned to take him with him. The bereaved and devout Christian family wasted no time in gathering together a suitcase filled with his young son's sarong and clothing. This suitcase was placed in the burial tomb and the family prayed that $\mathrm{Ne}$ ' Ke'te' would find these mementos enough to satisfy the longings for his son. The strategy was deemed a success when the son recovered shortly thereafter. While this action might have dismayed the early Dutch evangelists, for this Torajan family it was a perfectly natural solution to the problem at hand. They perceived no contradictions between their actions and their sense of what it means to be Protestant.

In $1984 \mathrm{I}$ attended the 17th Synod of the Toraja Church. Held in the South Sulawesi coastal town of Palopo, the Synod drew hundreds of Toraja Church ministers from throughout the archipelago, but only two Dutch ministers representing the mother church were in attendance. Some discussions focussed on how to address Christian Torajans' adherence to elements of the indigenous notions of soul. Significantly, several younger Torajan ministers, trained in a period when the idea of indigenizing Christianity had become less controversial, expressed confusion about the Bible's stance on spirits. One, for instance, asked for Biblical clarification of the 
notion that death is absolute, as she was uncertain whether belief in the post-mortem persistence of souls was acceptable for Christian Torajans and wanted to know how to advise her congregation.

The older, more conservative Dutch-trained members of the clergy, however, had clearly defined convictions about these matters. Just one month prior to the Synod, several of them had published a book on the topic, entitled Spirits and Mysterious Powers, under the auspices of the Toraja Church Theological Institute (Kobang et al. 1984). The authors maintain that, as the Bible does not answer all questions about the existence of spirits of the dead, devout Christians must refrain from contact with the spirit world. Dreams involving the dead are not to be interpreted as communicating the bombo's desires, and evil spirits or bombos, if encountered, are to be ignored, for God's power conquers all (Kobang et al. 1984:129-135).

It is still too soon to say whether Christian Torajans will accept this handbook as the putty that fills in the metaphysical gaps in the Bible. With current sociocultural changes undermining the basis of the traditional Torajan concept of soul (e.g., the shift from communal to individual orientations, a movement from a rank-based to a class-based society, etc.), the next few decades may see the gradual erosion of these autochthonous elements in the Christian Torajan conception of the soul. However, it is equally possible that the booklet's implicit recognition of Aluk to Dolo spirits will lend power to these beliefs, ultimately ensuring their endurance.

\section{CONCLUSION}

While conservative ministers of the Toraja Church tend to perceive the persistence of such indigenous beliefs as the result of incomplete catechism, ${ }^{16} \mathrm{I}$ am more inclined towards the interpretation proposed by Aragon (in press) who, in regarding Christian reformulations of tradition among the Tobaku of Indonesia, argues that "particular elements of...pre-Christian concept and practice fill in open or unresolved aspects of Christian Biblical canon" (also see Lehman 1987).

The aspects of indigenous soul conceptions drawn upon by Christian Torajans, seem to occur not randomly but precisely where Biblical delineations blur or metaphysical issues are not fully explained. For instance, the Bible makes no definitive statement pertaining to ghosts and spirits. Evil spirits are rarely touched upon in the Old Testament, although it is noted that one should not seek guidance from the spirits of the deceased but from God. In the New Testament spirits are more plentiful; however the Bible does not delineate the relation between evil spirits and the souls/spirits of the deceased. For Christian Torajans the traditional belief that many of these troublesome spirits derive from the unsatisfied souls of the dead is neither refuted nor confirmed, hence the persistence of the notion of bombo.

A second area of metaphysical mystery in Christian Biblical canon pertains to the significance of dreams involving the dead. In several Biblical episodes, God appears and communicates in dreams (for example, to Salome and Jacob). The Bible does not explicitly declare that the dead cannot do the same. For lay Christian Torajans, then, aluk to dolo notions of bombos communicating through dreams do not appear inharmonious with devotion to God. 
To sum up, this examination of Toraja soul beliefs suggests that there is an ongoing dialogue between Christian and aluk to dolo conceptions. Moreover, elements of the pre-Christian notion of soul that find their way into Christian understandings are not simply manifestations of superficial conversion or arbitrary survivals in the Tylorian sense. Rather, as Aragon (in press) maintains, there is some system to what is picked up and kept in this dialogue of religions. With regards to the soul, it is precisely where Biblical canon is hazy that Christian Torajans tend to draw on aluk to dolo images of soul.

\section{NOTES}

1. These terms vary in different regions of the Toraja highlands. The terms and concepts used in this paper are those of the Kesu' region of Tana Toraja Regency, where I spent 22 months conducting ethnographic research in 1984-1985, 1987, and 1989. The research was funded by a Fulbright Fellowship and a research grant from the University of Washington. While in the field I was sponsored by Hasanuddin University. I wish to thank my Torajan friends and teachers, both Christian and aluk to dolo. I am also indebted to the following individuals for their insightful comments on this essay: Bruce Calder, Elizabeth Coville, $O$. C. Edwards Jr., Greg LeRoy, Harvey Markowitz, Jay Miller, and Shusuke Yagi.

2. There are a variety of terms for indigenous Torajan religion. For instance, Hollan (1988a:277) uses the term Aluk Nene' (Way of the Ancestors) and Wellenkamp (1988:488) has written of Alukta (Our Way). My informants tended to favor the officially-recognized term Aluk to Dolo, although they spoke of Alukta on occasion, as well.

3. This contrasts with the neighboring Luwu area where the related concept of sumange' is highly elaborated (Errington 1990:51-57). Coville $(1988: 153,155)$ notes that the term sumanga' is seldom used in the northwestern highlands of Tana Toraja Regency and suggests that the more prevalent term deata (divine spirit) is roughly equivalent to sumanga'. NooyPalm (1979:128) observes that one of the alternate meanings of deata is soul of someone in life, but in the Kesu' area, where I worked, deata is more frequently used to refer to deified ancestors.

4. For discussions of the link between penaa and emotion in Toraja, see Hollan (1988b) and Wellenkamp (1984).

5. The Torajan term for insane is bomboan; that is, one who has the characteristics of a bombo.

6. For a detailed discussion of the significance of these effigies in Torajan society, see Adams (1987, 1988).

7. Nooy-Palm (1979:121) describes some of these obstacles. First the soul must traverse the River of the Dead (Salu Bombo), which is guarded by a cat (named Bali Karae). The cat prohibits the souls of criminals from proceeding to Puya, and flings them into a hollow filled with water buffalo excrement. From thieves, the cat claws back stolen goods (to be returned to the true owner when he or she eventually arrives at the bridge). Once past Bali Kare, the soul must brave the rickety, wildly swaying bridge over the River of the Dead before finally arriving at Puya, where one is judged by Pong Lalondong.

8. Some Torajans claim that the humans who become batitong are not necessarily animated by such disgruntled female souls, but are simply greedy individuals who have links with the world of evil spirits.

9. Coville (1988) and Nooy-Palm (1979:129) note that deata may also be used to refer to the soul of someone alive. This aspect of the concept seems to be more elaborated in the region 
where Coville worked. She describes these deata as guardian spirits and suggests that the concept is akin to the older, less-used concept of sumanga' (Coville 1988:98, 155). Moreover, people are "taken by deata" (naala deata), going into a trance state, as a part of the Maro ritual (Coville, personal communication).

10. Nooy-Palm (1979:129) says that the three words for soul (she does not discuss penaa) reflect the prevalence of a dual opposition in the tripartite Torajan universe. Linking bombo to the world of death and deata with the opposing upper world of life, she refrains from proposing that sumanga' is associated with the middle world of humans. Rather, she suggests that deata and bombo "find their unity in the human individual who combines in his personal self the two opposing aspects of all there is."

11. According to the Passomba Tedong litany, Puang Matua (The Old Lord) is the god of the dazzling sun who created the world. While scholars generally agree that he has long been a prominent aluk to dolo deity, many note that Christianity further elevated his status (NooyPalm 1979:118-119).

12. This prohibition failed, as the effigies are important symbols of elite identity. Aristocratic Christian Torajans continue to use them, arguing that they are no longer vessels of the soul but, rather, function as photographs.

13. Partially because livestock sacrifice at funerals and inheritance rights were intertwined. 14. In fact, some Torajans say that in the southern regions of Tana Toraja, the souls of the highest ranking nobles (Puang) bypass Puya and go directly to the heavens to become deities. 15. Rodgers (1981:61) presents a case involving a similar Protestant approach to indigenous spirits among the Sipirok Batak of Sumatra. Here, too, a local preacher sees traditional spirits not as "imaginary relics of animism" but rather as real, but capable of being subdued by God. 16. As noted by Hoskins (1987), some anthropologists have drawn similar conclusions regarding processes of religious transformation in other areas of Indonesia.

\section{BIBLIOGRAPHY}

Adams, K. M. 1987. Image and Identity: Reconceptualizations of Carved Torajan Effigies in the Context of Change. Paper presented at the Association for Asian Studies Annual Meeting, Boston.

1988. Carving a New Identity: Ethnic and Artistic Change in Tana Toraja (Indonesia). Ph.D. Dissertation, University of Washington, Seattle.

Aragon, L. V. (in press). Reorganizing the Cosmology: The Reinterpretation of Traditional Deities' and Ancestors' Roles in Central Sulawesi Protestant Concept and Practice. Protestants and Tradition in Southeast Asia, ed. C. A. Kamumerer. Singapore.

Atkinson, J. 1983. Religions in Dialogue: The Construction of an Indonesian Minority Religion. American Ethnologist 10:684-696.

Bigalke, T. 1981. A Social History of "Tana Toraja" 1870-1965. Doctoral Dissertation, University of Wisconsin-Madison.

Coville, E. 1988. A Single Word Brings to Life: The Maro Ritual in Tana Toraja (Indonesia). Doctoral Dissertation, University of Chicago.

Crystal, E., and S. Yamashita. 1987. Power of Gods: Ma'Bugi' Ritual of the Sa'dan Toraja. Indonesian Religions in Transition, eds. R. Kipp and S. Rodgers, pp.48-70. Tucson.

Downs, R. E. 1955. Headhunting in Indonesia. Bijdragen tot de Taal- Land-en Volkenkund 3.

Errington, S. 1989. Meaning and Power in a Southeast Asian Realm. Princeton. 
Fox, J. 1973. On Bad Death and the Left Hand: A Study of Rotinese Symbolic Inversions. Right and Left: Essays on Dual Symbolic Classification, ed. R. Needham, pp. 342368. Chicago.

Geertz, C. 1973. "Internal Conversion" in Contemporary Bali. The Interpretation of Cultures, ed. C. Geertz, pp. 170-189. New York.

Hollan, D. 1988a. Pockets Full of Mistakes: The Personal Consequences of Religious Change in a Toraja Village. Oceania 58:275-289.

1988b. Staying "Cool" in Toraja: Informal Strategies for the Management of Anger and Hostility in a Non-Violent Society. Ethos 16:52-72.

Hoskins, J. 1987. Entering the Bitter House: Spirit Worship and Conversion in West Sumba. Indonesian Religions in Transition, eds. R. Kipp and S. Rodgers, pp. 136-160. Tucson.

Kantor Statistik. 1983. Tana Toraja Dalam Angkat. Makale, Indonesia.

Kipp, R., and S. Rodgers. 1987. Indonesian Religions in Transition. Tucson.

Kobong, Th., A. Rumpua, J. R. Pasolon, B. Plaisier, J. Lebang, and J. A. Sarira. 1884. Roh-Roh dan Kuasa-Kuasa Gaib. Rantepao (Indonesia).

Koubi, J. 1982. Rambu Solo', "La Fumee Descend": Le Culte des Morts Chez les Toradja du Sud. Paris.

Lehman, F. K. 1987. Burmese Religion. The Encyclopedia of Religion, ed. M. Eliade, pp. 574-580. New York.

MacGregor, G. 1987. Soul: Christian Concept. The Encyclopedia of Religion, ed. M. Eliade, pp. 455-460. New York.

Mills, R. 1975. The Reconstruction of Proto South Sulawesi. Archipel 10:205-225.

Needham, R. 1976. Skulls and Causality. Man 11:71-88.

Nooy-Palm, C. H. M. 1979. The Sa'dan Toraja: A Study of their Social Life and Religion. Vol. I: Organization, Symbols and Beliefs. The Hague.

1986. The Sa'dan Toraja: A Study of their Social Life and Religion. Vol. II: Rituals of the East and West. Dordrecht, Netherlands.

Ranger, T. 1987. An Africanist Comment. In Frontiers of Christian Evangelism, special issue of American Ethnologist 14:182-185.

Rodgers, S. 1981. Adat, Islam and Christianity in a Batak Homeland. Athens, Ohio.

Sarira, J. A. 1975. Benih Yang Tumbuh 6: Suatu Survey Mengenai Gereja Toraja Rantepao. Rantepao, Indonesia.

Tangdilintin, P. 1981. "Padang Bombo" the Heaven of the Torajanese. Indonesia Magazine 2:43-46.

Tammu, J., and H. van der Veen. 1972. Kamus Toradja-Indonesia. Rantepao, Indonesia.

Veen, H. van der. 1966. The Sa'dan Toraja Chant for the Deceased. 's-Gravenhage.

Weinstock, J. A. 1987. Kaharingan: Life and Death in Southern Borneo. Indonesian Religions in Transition, eds. R. Kipp and S. Rodgers, pp. 71-97. Tucson.

Wellenkamp, J. 1984. A Psychocultural Study of Loss and Death among the Toraja. Ph.D. Dissertation, University of California, San Diego.

1988. Notions of Grief and Catharsis Among the Toraja. American Ethnologist 15:486-500. 